\title{
ANTIPROLIFERATIVE ACTIVITY OF ELEPHANTOPUS SCABER MEDIATED SILVER NANOPARTICLES AGAINST MCF-7, A-549, SCC-40, AND COL0-205 HUMAN CANCER CELL LINES
}

\author{
ASHWINI S SHINDE, VIJAY D MENDHULKAR* \\ Department of Botany, The Institute of Science, Mumbai, Maharashtra, India. Email: profmendhulkar@gmail.com \\ Received: 27 November 2019, Revised and Accepted: 31 December 2019
}

\begin{abstract}
Objective: To unearth the applications of nanotechnology in medicine has become imperative with all the advancements in the technique. In the current study, we have attempted to exploit the anticancer ability of the green synthesized silver nanoparticles (AgNPs).

Methods: The AgNPs were synthesized using 60\% methanol (H-MeOH) Elephantopus scaber leaf extract, characterized, and discussed priorly. The effect of AgNPs was studied on the human breast (MCF-7), lung (A-549), oral (SCC-40), and colon (COLO-205) cancer cell lines through sulforhodamine
\end{abstract} B assay. We also carried out the synergistic activity with standard drug adriamycin (ADR).

Results: According to the results obtained, AgNPs showed good antiproliferative activity with GI s0 $_{2} 10 \mu \mathrm{g} / \mathrm{ml}$ on MCF-7, A-549, and SCC-40 cell lines when compared with the standard drug ADR. However, for COLO-205 cell line, the impact was $17.4 \mu \mathrm{g} / \mathrm{ml}$ and thus the treatment was less effective.

Conclusion: The synergistic effect of AgNPs+ADR was even better for all the four cell lines than that of the AgNPs alone.

Keywords: Silver nanoparticles, Elephantopus scaber, Anticancer, Sulforhodamine B assay, MCF-7, A-549, SCC-40, COLO-205.

(C) 2020 The Authors. Published by Innovare Academic Sciences Pvt Ltd. This is an open access article under the CC BY license (http://creativecommons. org/licenses/by/4. 0/) DOI: http://dx.doi.org/10.22159/ajpcr.2020.v13i2.36497

\section{INTRODUCTION}

Irrespective of region, state, or a country, cancer affects everyone without discriminating against different types of human races. Cancer is responsible for causing about 0.3 million deaths every year. Unawareness is not the only problem but also the other reasons that have contributed to increased mortality rate due to cancer in India include the inability to prevent, diagnose as well as treat the disease. Worldwide tremendous resources are being invested in prevention, diagnosis, and treatment of cancer [1,2]. Thus, the key focus of several pharmaceutical companies is toward the discovery and development of anticancer agents. The identification of cytotoxic compounds led to the development of anticancer therapeutics for several decades. Nanotechnology is one of the most active research fields in modern science and technology [3]. In recent times, several researchers have been reported to achieve success in the synthesis of metal nanoparticles (NPs) obtained from extracts of plant parts. Conventionally, the chemical and physical methods used to synthesize NPs are expensive and often raise questions of environmental risk, involving the use of toxic, and hazardous chemicals. The advancements of green synthesis over chemical and physical methods are environmentally friendly, cost effective, and easily scaled up for large scale synthesis of NPs [4].

Regarding silver NPs (AgNPs), compounds possessing antiangiogenic properties are known for their potential ability to block the activity of abnormally expressed signaling proteins, such as Ras and Akt, cytokinebased therapies, DNA or protein-based vaccines against specific tumor markers, and tyrosine kinase inhibitors which exhibit a consistent antitumor effect [5]. The cytotoxic effects of silver are the result of the active physicochemical interaction of silver atoms with the functional groups of intracellular proteins, as well as with the nitrogen bases and phosphate groups in DNA [6].

Thus, in the present study, the aim was targeted to investigate the response of the medicinal plant, Elephantopus scaber L. for the phytosynthesis of nanoscale particles in the leaf extract using metal salt (Ag) and to evaluate their anticancer application on MCF-7, A-549, SCC40, and COLO-205 malignant cell lines.

\section{METHODS}

\section{Preparation of plant extract}

E. scaber L. was used as an experimental system for the phytosynthesis of AgNPs and further to check its effect on cancer cell culture. The healthy and disease-free plant leaves of E. scaber were collected from Matheran, Raigad district, MS, India, in the month of August 2015. The plant was taxonomically authenticated from the Department of Botany, Blatter Herbarium, St. Xavier's College, Mumbai (Voucher specimen no. 2943 of H. Santapau). The plant material was washed, cleaned, air-dried, and finely powdered. The Soxhlet extraction of E. scaber leaf powder was carried out using solvents as $60 \%$ methanol $(\mathrm{H}-\mathrm{MeOH})$ for $24 \mathrm{~h}$ or till the solvent appears to be colorless at temperatures $70^{\circ} \mathrm{C}$. The extract was filtered using Whatman filter paper and concentrated using a rotary evaporator. It was further dried completely and kept in the refrigerator $\left(4^{\circ} \mathrm{C}\right)$ for further analysis.

\section{Experimental synthesis of AgNPs}

Silver nitrate $\left(\mathrm{AgNO}_{3}\right)$ was procured from Sigma-Aldrich with 99.9\% purity. The $\mathrm{H}-\mathrm{MeOH}$ Soxhlet extract was used for the synthesis of AgNPs. The $\mathrm{H}-\mathrm{MeOH}$ extract ( $2 \mathrm{mg} / \mathrm{ml}$ ) was dissolved in $60 \%$ methanol $(10 \mathrm{ml})$ using a water bath sonicator for about 15-20 min. This extract was then diluted to $100 \mathrm{ml}$ with distilled water and homogenized. The $\mathrm{pH}$ of the solution was adjusted to ten by potassium hydroxide $(\mathrm{KOH}-1 \mathrm{M})$ solution. The $\mathrm{AgNO}_{3}$ salt was added to the solution so as to obtain $4 \mathrm{mM}$ of concentration. It was kept on a shaker in the dark for overnight. The solution turned from yellow-amber color to dark brown color. The change in color indicates the synthesis of AgNPs. The NPs formed were recovered by centrifugation at $10,000 \mathrm{rpm}$ for $30 \mathrm{~min}$ at $10^{\circ} \mathrm{C}$ and washed 3 times with distilled water by centrifugation. The NPs obtained were dried completely so as to obtain crystals and were stored at $4^{\circ} \mathrm{C}[7]$. 
Anticancer studies using sulforhodamine B (SRB) assay

For the present study, the effect of AgNPs was studied on four human cancer cell lines were selected, namely, breast cancer cell line (MCF-7), colon cancer cell line (COLO-205), lung cancer cell line (A-549), and oral cancer cell line (SCC-40) at Advanced Centre for Treatment, Research and Education in Cancer (ACTREC), Tata Memorial Centre, Mumbai. The SRB assay was performed [8].

\section{RESULTS}

The obtained results of the green synthesis of AgNPs using E. scaber and anticancer activities on selected human cancer cell lines are discussed below. The synthesized NPs were further characterized using ultraviolet (UV)-visible spectrophotometer, nanoparticle tracking analyzer (NTA), X-ray diffraction, Fourier transform infrared, scanning electron microscopy, and transmission electron microscopy as per discussed in our previous paper [1].

\section{Anticancer activity}

The present study was to evaluate our NPs and its synergistic effect for antiproliferative properties in vitro against human cancer cell lines.
The treatment of AgNPs, AgNPs+adriamycin (ADR), H-MeOH extract, and $\mathrm{H}-\mathrm{MeOH}$ extract+ADR was administered on breast cancer cell line (MCF-7), lung cancer cell line (A-549), oral cancer cell line (SCC-40), and colon cancer cell line (COLO-205) by performing SRB assay. ADR also known as doxorubicin drug was used as a reference compound. The susceptibility of cells to the drug exposure was characterized by $\mathrm{GI}_{50}$ (concentration of drug causing 50\% inhibition of cell growth), total growth inhibition (TGI) (concentration of drug causing total inhibition of cell growth), and $\mathrm{LC}_{50}$ (concentration of drug causing $50 \%$ cell kill) values (Table 1). The growth curve for the anti-cancer activity for different concentrations is shown in Fig. 1.

\section{Application on human breast cancer cell line (MCF-7)}

MCF-7 cells were treated with all the concentrations for $24 \mathrm{~h}$ to show profound morphological changes characterized by cytotoxicity, shrinkage, and irregular shape. The microscopic photos of various treatments are illustrated in Fig. 2. The highest activity was noted for AgNPs, giving $-72.0 \%$ control growth at the $20 \mu \mathrm{g} / \mathrm{ml}$ concentration, which is greater than any concentration of positive control, ADR.

Table 1: $\mathrm{LC}_{50}$, TGI, and $\mathrm{GI}_{50}$ values of MCF7, A-549, SCC-40, and COLO-205 cell lines after treatment with test drugs

\begin{tabular}{|c|c|c|c|c|c|c|c|c|c|c|c|c|}
\hline \multirow[t]{3}{*}{ Samples } & \multicolumn{12}{|c|}{ Drug concentrations $(\mu \mathrm{g} / \mathrm{ml})$ calculated from graph $(n=3)$} \\
\hline & \multicolumn{3}{|c|}{ MCF-7 } & \multicolumn{3}{|l|}{ A-549 } & \multicolumn{3}{|c|}{ SCC-40 } & \multicolumn{3}{|c|}{ COLO-205 } \\
\hline & $\mathbf{L C}_{50}$ & TGI & $\mathbf{G I}_{50} *$ & $\mathrm{LC}_{50}$ & TGI & $\mathbf{G I}_{50} *$ & $\mathrm{LC}_{50}$ & TGI & $\mathbf{G I}_{50} *$ & $\mathrm{LC}_{50}$ & TGI & $\mathbf{G I}_{50} *$ \\
\hline AgNPs & 58.2 & $<10$ & $<10$ & 72.5 & 23.8 & $<10$ & NE & NE & $<10$ & 65.2 & 41.3 & 17.4 \\
\hline AgNPs+ADR & $<10$ & $<10$ & $<10$ & $<10$ & $<10$ & $<10$ & $<10$ & $<10$ & $<10$ & $\mathrm{NE}$ & $\mathrm{NE}$ & $<10$ \\
\hline $\mathrm{H}-\mathrm{MeOH}$ & $>80$ & $>80$ & $>80$ & $>80$ & $>80$ & $>80$ & $\mathrm{NE}$ & $\mathrm{NE}$ & $>80$ & $>80$ & $>80$ & $>80$ \\
\hline $\mathrm{H}-\mathrm{MeOH}+\mathrm{ADR}$ & $\mathrm{NE}$ & $\mathrm{NE}$ & $<10$ & $\mathrm{NE}$ & $\mathrm{NE}$ & $<10$ & $\mathrm{NE}$ & NE & $<10$ & $<10$ & $<10$ & $<10$ \\
\hline
\end{tabular}

*(Concentration of drug causing 50\% inhibition of cell growth) when $<10 \mu \mathrm{g} / \mathrm{ml}$ : Anticancer activity shown by the sample. TGI: Total growth inhibition, ADR:

Adriamycin, AgNPs: Silver nanoparticles

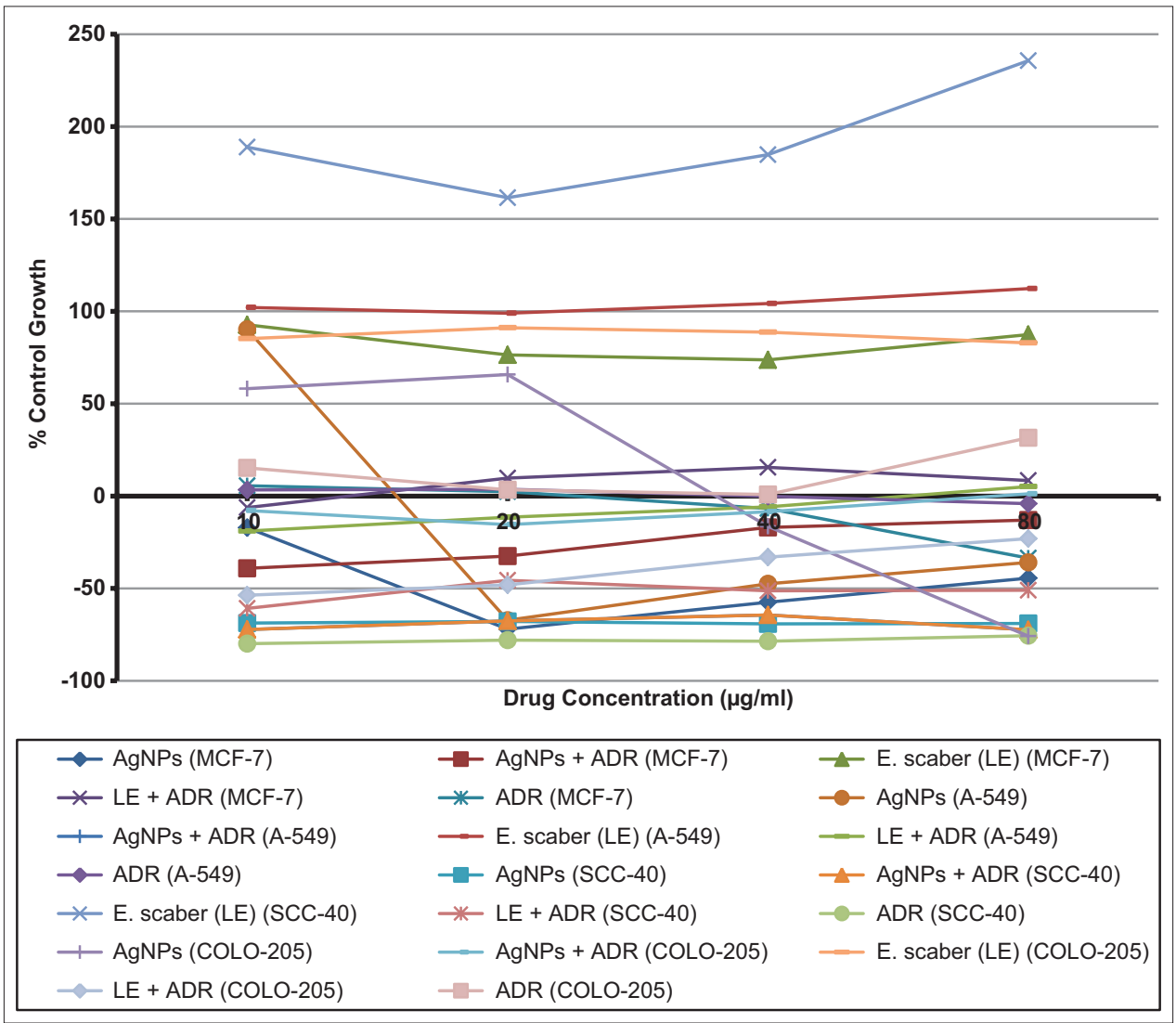

Fig. 1: Growth curve of cancer cell lines for Elephantopus scaber H-MeOH extract, silver nanoparticles, and its synergistic activity with adriamycin 
For this cell line, AgNPs alone treatment was superior compared to the AgNPs+ADR combination treatment especially for $20 \mu \mathrm{g} / \mathrm{ml}$ concentration. The concentrations of AgNPs at 20,40, and $80 \mu \mathrm{g} / \mathrm{ml}$ were found to have elicited higher activity than that of AgNPs+ADR. Lower activity was found in E. scaber $\mathrm{H}-\mathrm{MeOH}$ extract, showing control growth values of $95.7 \%$ at $10 \mu \mathrm{g} / \mathrm{ml}$ concentration. After combining the $\mathrm{H}-\mathrm{MeOH}$ extract with $\mathrm{ADR}, 10 \mu \mathrm{g} / \mathrm{ml}$ concentrations showed the lowest growth value of $-6.2 \%$. It may be attributed to the effect of ADR alone in the synergistic treatment of $\mathrm{H}-\mathrm{MeOH}$ extract. $\mathrm{The}_{\mathrm{GI}}$ value for AgNPs, AgNPs+ADR, and H-MeOH extract+ADR was $<10 \mu \mathrm{g} / \mathrm{ml}$, which is in tandem to that of the positive control, ADR. The synergistic effect of AgNPs+ADR shows $<10 \mu \mathrm{g} / \mathrm{ml}$ values for $\mathrm{GI}_{50}, \mathrm{TGI}$, and $\mathrm{LC}_{50^{\prime}}$, but AgNPs alone showed $<10 \mu \mathrm{g} / \mathrm{ml}$ for only $\mathrm{GI}_{50}$ and TGI. MCF-7 cells proliferation was significantly inhibited by AgNPs with an $\mathrm{LC}_{50}$ value of $58.2 \mu \mathrm{g} / \mathrm{ml}$ of concentration.

\section{Application on human lung cancer cell line (A-549)}

The images showing the effect of various treatments are accessible in Fig. 3. The percent control growth was found to be decreasing with increasing concentration of test compounds, and it is shown in Fig. 1.
There was no linear response between the drug concentration and percent cell growth for the AgNPs and AgNPs+ADR. Effect of E. scaber mediated synthesis AgNPs was found to be better than the other test compounds with concentration at $20 \mu \mathrm{g} / \mathrm{ml}$. The combined effect of AgNPs+ADR also gives the least percent control growth at $10 \mu \mathrm{g} / \mathrm{ml}$. The AgNPs as compared to ADR give better results at the concentrations 20,40 , and $80 \mu \mathrm{g} / \mathrm{ml}$. The results showed that A-549 cell proliferation was significantly inhibited by AgNPs with an $\mathrm{LC}_{50}$ value of $72.5 \mu \mathrm{g} / \mathrm{ml}$ of the concentration and TGI value of $23.8 \mu \mathrm{g} / \mathrm{ml}$ of the concentration. AgNPs treatment revealed $\mathrm{GI}_{50}$ value (Table 1) below $10 \mu \mathrm{g} / \mathrm{ml}$ which is in par with that of ADR (positive control), thus showing high anticancer activity.

\section{Application on human oral cancer cell line (SCC-40)}

Results of cytotoxicity on human oral cancer SCC-40 cell lines are tabularized in Table 1 and graphically represented in Fig. 1. Here, AgNPs+ADR showed maximum activity followed by AgNPs, $\mathrm{H}-\mathrm{MeOH}+\mathrm{ADR}$, and $\mathrm{H}-\mathrm{MeOH}$ extract. The synergistic antiproliferative activities were evident in SCC-40 cell line. AgNPs and E. scaber $\mathrm{H}-\mathrm{MeOH}$
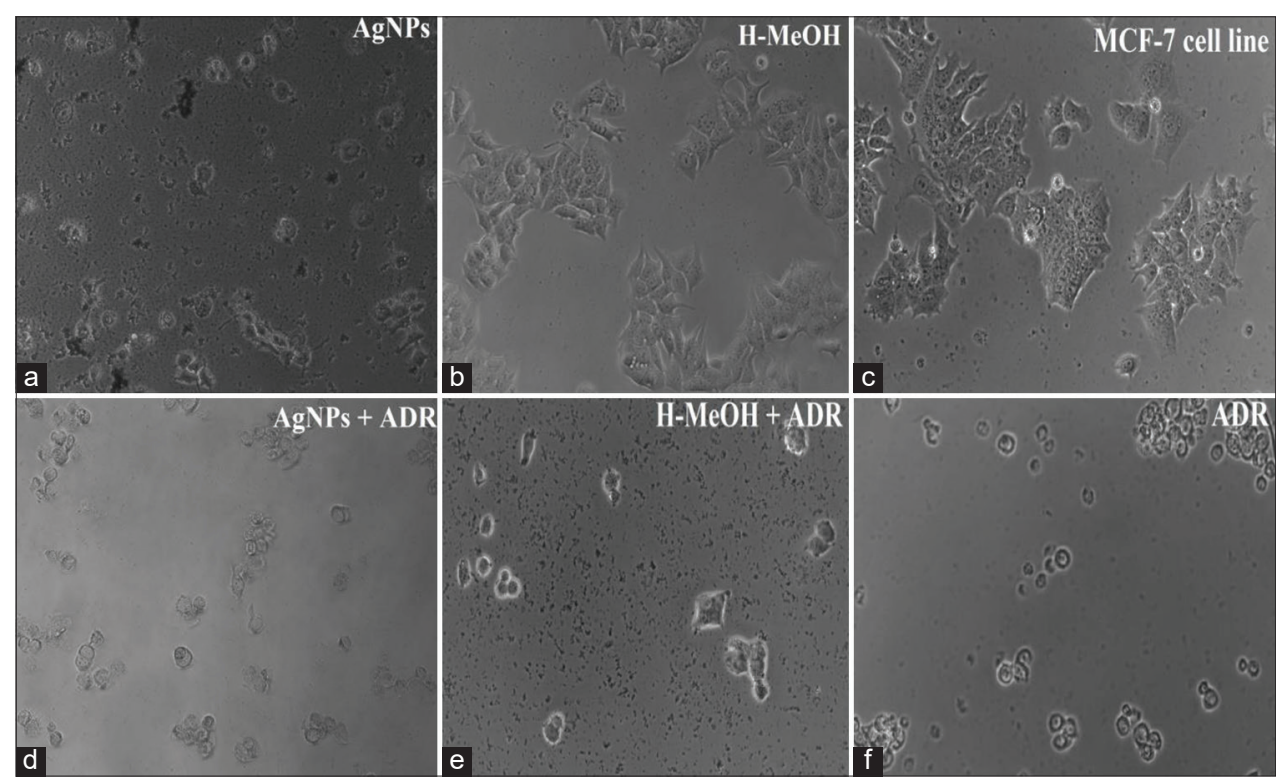

Fig. 2: (a-f) Effect of test drug on MCF-7 as observed under inverted microscope
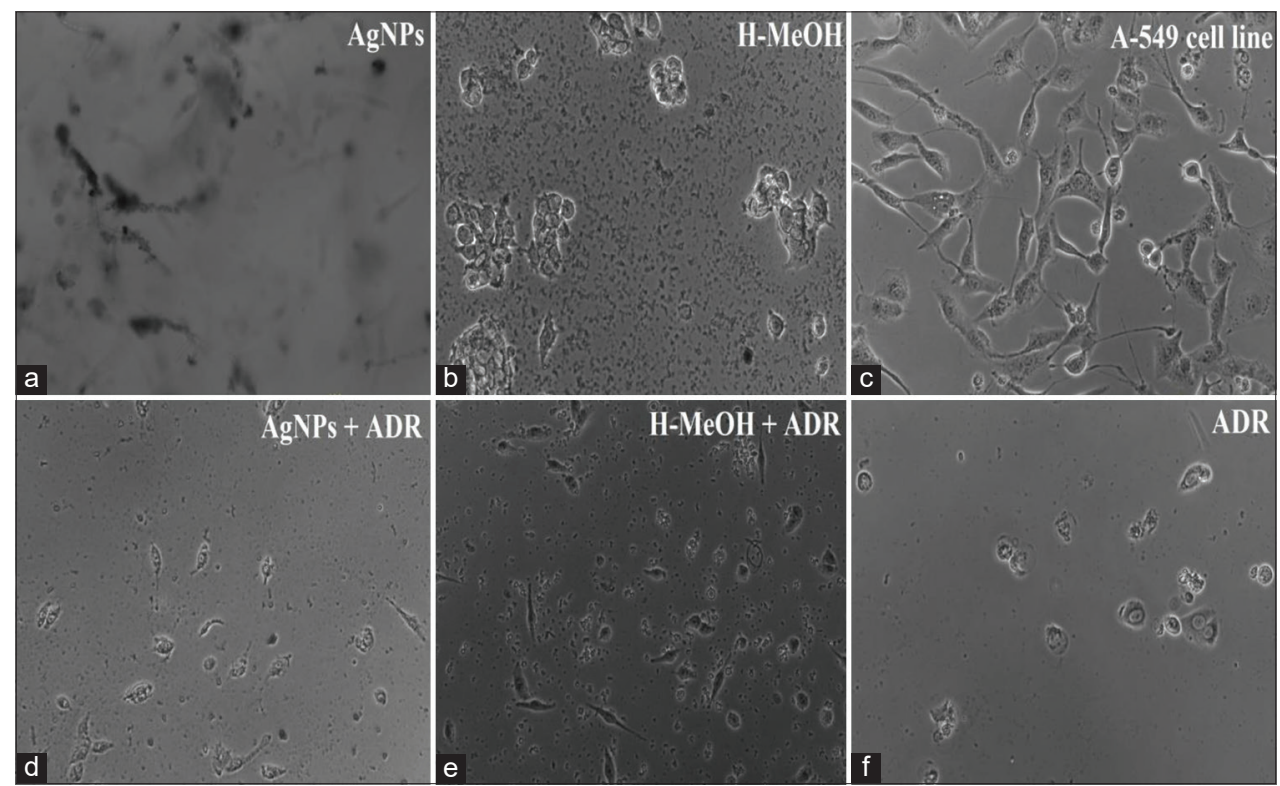

Fig. 3: (a-f) Effect of test drug on A-549 as observed under inverted microscope 
extract give better results $(<10 \mu \mathrm{g} / \mathrm{ml})$ when combined with ADR. Both AgNPs and ADR demonstrated $<10 \mu \mathrm{g} / \mathrm{ml}$ value for $\mathrm{GI}_{50}$ (Table 1 ); hence, both are antiproliferative agents for oral cancer cells. The cytotoxic effect of these treatments was visualized under an inverted microscope which is shown in Fig. 4. SCC-40 cells treated with the different treatments for $24 \mathrm{~h}$ show morphological changes such as shrinkage, low cell count, and irregular shape which are the characteristic of cytotoxicity.

\section{Application on human colon cancer cell line (COLO-205)}

In the case of COLO-205, all the samples exhibited low activity for the first three concentrations, but the $80 \mu \mathrm{g} / \mathrm{ml}$ concentration range produced strong cytotoxicity in AgNPs and $\mathrm{H}-\mathrm{MeOH}$ extract treatments while the synergistic effects of the samples (AgNPs+ADR and $\mathrm{H}-\mathrm{MeOH}+\mathrm{ADR}$ ) showed maximum activity (Table 1 ). The test samples when combined with the ADR, give better results compared to the individual test samples. The $\mathrm{GI}_{50}$ value for the synergistic effects of the test samples showed $<10 \mu \mathrm{g} / \mathrm{ml}$ along with the ADR standard while the $\mathrm{GI}_{50}$ value for AgNPs sample was observed to be $17.4 \mu \mathrm{g} / \mathrm{ml}$ while $\mathrm{H}-\mathrm{MeOH}$ extract showed $\mathrm{GI}_{50} \geq 80 \mu \mathrm{g} / \mathrm{ml}$. After SRB staining, the cytotoxic effect of these treatments was visualized under the inverted microscope showing morphological changes such as shrinking of cells, low cell count, and irregular shape which shows the cytotoxicity of the treatments (Fig. 5). The results for cytotoxicity on human colon COLO-205 cancer cell lines are tabularized in Table 1 and graphically symbolized in Fig. 1.

\section{DISCUSSION}

Similar results were found where AgNPs synthesized using leaf extract of Aegle marmelos were showed to have particle size of $15-30 \mathrm{~nm}$ with stable spherical structures [9]. The AgNPs were synthesized using Withania somnifera, A. marmelos, and Taraxacum officinale plant extract. The formed NPs were of irregular shapes with a size of 94, 26, and $18 \mathrm{~nm}$, respectively. The antineoplastic potential of AgNPs was assessed by 3-(4,5-dimethylthiazol-2-yl)-2,5-diphenyltetrazolium bromide (MTT) assay with its $\mathrm{IC}_{50}$ values as $205.76 \pm 0.37,251.25 \pm 0.59$, and $215.51 \pm 0.41 \mu \mathrm{g} / \mathrm{ml}$, respectively, against MCF-7 cell line [10]. AgNPs synthesized using seaweed Ulva lactuca inhibits the cell proliferation of MCF-7 with $\mathrm{IC}_{50}\left(\mathrm{GI}_{50}\right)$ value of $37 \mu \mathrm{g} / \mathrm{ml}$ of the concentration [11].
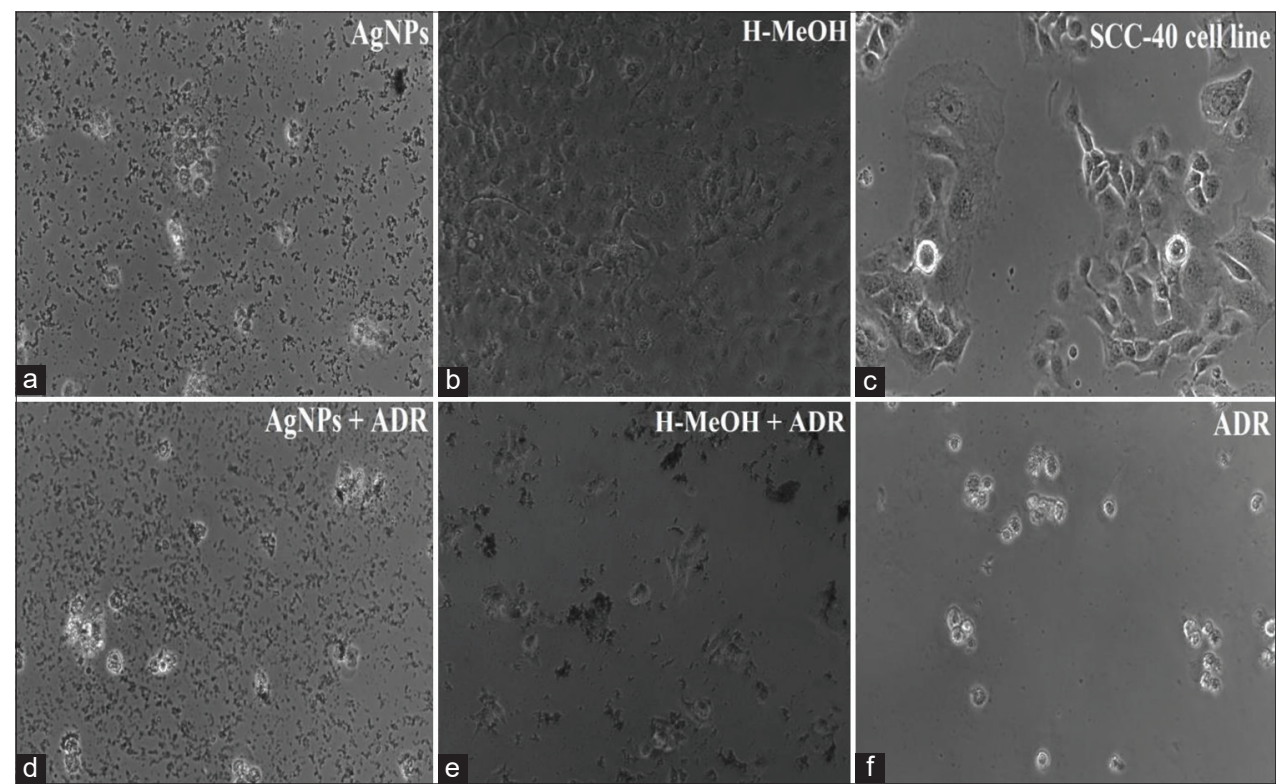

Fig. 4: (a-f) Effect of test drug on SCC-40 as observed under inverted microscope

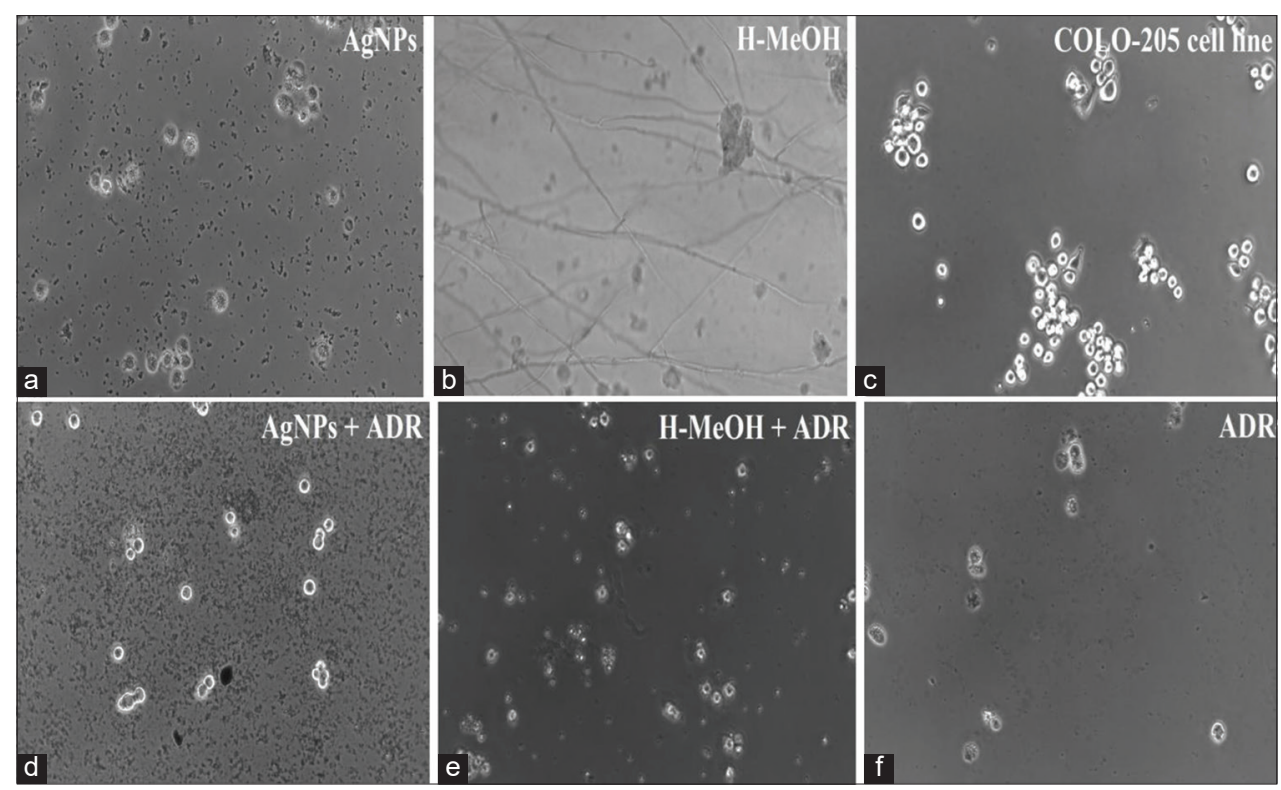

Fig. 5: (a-f) Effect of test drug on COLO-205 as observed under inverted microscope 
In another report, the $\mathrm{IC}_{50}\left(\mathrm{GI}_{50}\right)$ value of cell inhibition of AgNPs was observed at $3.043 \mu \mathrm{l} / \mathrm{ml}$. The complete cell inhibition (TGI) of the breast cancer cell line was obtained at a maximum concentration of $25 \mu \mathrm{g} / \mathrm{ml}[12]$.

AgNPs synthesized using Dimocarpus longan (L.) indicated an $\mathrm{IC}_{50}$ value of $5.33 \pm 0.37 \mu \mathrm{g} / \mathrm{ml}$ for lung cancer $\mathrm{H} 1299$ cell line. Approximately $50 \%$ of lung cancer cells died when treated with AgNPs at the concentration between 5 and $8 \mu \mathrm{g} / \mathrm{ml}$. A large number of in vitro studies stated above point out that the AgNPs are toxic to mammalian cells [13]. Antiproliferative activity of AgNPs using Inonotus obliquus extract against A-549 human lung cancer cell line. AgNPs significantly inhibited cell proliferation in A-549 (51.61\%) cells [14]. Similarly, our investigation also provides conclusive evidence for the cytotoxic effect of biosynthesized AgNPs against lung cancer A-549 cell line.

The anticancer studies of AgNPs synthesized using Salacia chinensis bark. The in vitro anticancer assay demonstrated an $\mathrm{IC}_{50}=14.37 \mu \mathrm{g} / \mathrm{ml}$ against oral (KB cells) cancer cell lines which confirms its potent anticancer action [15]. Furthermore, the AgNPs synthesized using leaf extract of Piper betle revealed to have strong activity against oral (KB) carcinoma cells by MTT assay [16].

AgNPs embedded into specific polysaccharide extracellular polymeric substances (EPS). This AgNPs-EPS matrices were tested against colon (HT-29, HCT-116, and Caco-2) cancer cell lines. The $\mathrm{IC}_{50}$ value for HT29, HCT-116, and Caco-2 was reported to be $20 \pm 2,26 \pm 2$, and $34 \pm 4$, respectively [17].

On the basis of our findings, it is unearthed that the studied cancer cell lines response positively to the doses of treatment samples, indicating encouraging results toward antiproliferative properties of E. scaber mediated AgNPs. The findings are much compatible even when compared with standard drug ADR which is used in cancer therapeutics. However, when the results of studied all the four cell lines are compared then it was noted that AgNPs when treated to MCF-7, A-549, and SCC-40 showed best antiproliferative results at $20 \mu \mathrm{g} / \mathrm{ml}$, $20 \mu \mathrm{g} / \mathrm{ml}$, and $40 \mu \mathrm{g} / \mathrm{ml}$ with $\mathrm{GI}_{50}<10 \mu \mathrm{g} / \mathrm{ml}$ which is in par with that of ADR - the positive control, thus showing superior anticancer activities over the drug, ADR, while COLO-205 showed better results at $80 \mu \mathrm{g} / \mathrm{ml}$ with $\mathrm{GI}_{50}=17.4 \mu \mathrm{g} / \mathrm{ml}$.

\section{CONCLUSION}

We carried out the studies on anticancer applications of AgNPs synthesized using E. scaber $\mathrm{H}-\mathrm{MeOH}$ extract. Visual observations of color change from yellow to dark brown-black confirmed the synthesis of AgNPs. UV-visible spectrophotometer confirmed the AgNPs with a peak at $415 \mathrm{~nm}$. NTA analysis revealed the mean size of the AgNPs as $40 \mathrm{~nm}$ with a frequency of $7.29 \times 10^{8}$ particles $/ \mathrm{ml}$. The anticancer abilities were studied of AgNPs which were studied on MCF-7 human breast cancer, A-549 human lung cancer, SCC-40 human oral cancer, and COLO-205 human colon cancer cell lines with reference of standard anticancer drug ADR using the SRB assay. According to the cytotoxic analysis, AgNPs are good antiproliferative agents on MCF-7, A-5479, and SCC- 40 cell lines, giving $\mathrm{GI}_{50}<10 \mu \mathrm{g} / \mathrm{ml}$, while for COLO-205 the $\mathrm{GI}_{50}$ was reported to be $17.4 \mu \mathrm{g} / \mathrm{ml}$. The synergistic drug combinations gave better results on the entire four cell lines with $<10 \mu \mathrm{g} / \mathrm{ml}$. The findings of this study exhibited efficient antiproliferative results of $E$. scaber $\mathrm{H}-\mathrm{MeOH}$-mediated AgNPs on studied human cancer cell lines.

\section{ACKNOWLEDGMENT}

We acknowledge officer-in-charge of in vitro SRB assay for anticancer activity evaluation of drugs, anticancer drug screening facility, ACTREC, Tata Memorial Centre, Kharghar, Navi Mumbai, MS, India, and The Institute of Science, Mumbai, for providing facilities.

\section{AUTHORS' CONTRIBUTION}

Ashwini S. Shinde - A researcher, worked out the concept using laboratory techniques, research article writer, studying for Ph.D. Biotechnology at The Institute of Science, Mumbai - 32.

Prof. Vijay D. Mendhulkar - Professor and supervisor of the researcher Ms Ashwini S. Shinde, concept development, and script correction.

\section{CONFLICTS OF INTEREST}

We declare that we have no conflicts of interest.

\section{AUTHOR'S FUNDING}

This research did not receive any specific grant from funding agencies in the public, commercial, or not-for-profit sectors.

\section{REFERENCES}

1. Kharat SN, Mendhulkar VD. Synthesis, characterization and studies on antioxidant activity of silver nanoparticles using Elephantopus scaber leaf extract. Mater Sci Eng C Mater Biol Appl 2016;62:719-24.

2. Mallath MK, Taylor DG, Badwe RA, Rath GK, Shanta V, Pramesh CS, et al. The growing burden of cancer in India: Epidemiology and social context. Lancet Oncol 2014;15:e205-12.

3. Niemeyer CM. Nanobiotechnology. In: Reviews in Cell Biology and Molecular Medicine. Weinheim: Wiley-VCH Verlag GmbH and Co., $\mathrm{KGaA} ; 2006$.

4. Raut RW, Lakkakula JR, Kolekar NS, Mendhulkar VD, Kashid SB. Phytosynthesis of silver nanoparticle using Gliricidia sepium (Jacq.). Curr Nanosci 2009;5:117-22.

5. Holtz RD, Souza Filho AG, Brocchi M, Martins D, Durán N, Alves OL. Development of nanostructured silver vanadates decorated with silver nanoparticles as a novel antibacterial agent. Nanotechnology 2010;21:185102.

6. Sriram MI, Kanth SB, Kalishwaralal K, Gurunathan S. Antitumor activity of silver nanoparticles in Dalton's lymphoma ascites tumor model. Int J Nanomedicine 2010;5:753-62.

7. Yadav A, Mendhulkar VD. Antiproliferative activity of Camellia sinensis mediated silver nanoparticles on three different human cancer cell lines. J Cancer Res Ther 2018;14:1316-24.

8. Vichai V, Kirtikara K. Sulforhodamine B colorimetric assay for cytotoxicity screening. Nat Protoc 2006;1:1112-6.

9. Patil S, Sivaraj R, Rajiv P, Venckatesh R, Seenivasan R. Green synthesis of silver nanoparticle from leaf extract of Aegle marmelos and evaluation of its antibacterial activity. Int J Pharm Pharm Sci 2015;7:169-73.

10. Amudha CK, Deeba F, Rajarajan P. Characterization and anti-neoplastic potential of phytofabricated silver nanoparticles on human breast cancer cell line (MCF-7). Int J Appl Pharm 2019;11:70-7.

11. Devi JS, Bhimba BV, Ratnam K. Anticancer activity of silver nanoparticles synthesized by the seaweed Ulva lactuca in vitro. Sci Rep 2012;1:242-8

12. Firdhouse MJ, Lalitha P. Biosynthesis of silver nanoparticles and its applications. J Nanotechnol 2015;2015:1-18

13. He Y, Du Z, Ma S, Liu Y, Li D, Huang H, et al. Effects of greensynthesized silver nanoparticles on lung cancer cells in vitro and grown as xenograft tumors in. Int J Nanomedicine 2016;11:1879-87.

14. Nagajyothi PC, Sreekanth TV, Lee JI, Lee KD. Mycosynthesis: Antibacterial, antioxidant and antiproliferative activities of silver nanoparticles synthesized from Inonotus obliquus (Chaga mushroom) extract. J Photochem Photobiol B 2014;130:299-304.

15. Jadhav K, Deore S, Dhamecha D, Jagwani S, Jalalpure S, Bohara R. Phytosynthesis of silver nanoparticles: Characterization, biocompatibility studies, and anticancer activity. ACS Biomater Sci Eng 2018;4:892-9.

16. Preethi R, Padma PR. Anticancer activity of silver nanobioconjugates synthesized from Piper betle leaves extract and its active compound eugenol. Int J Pharm Pharm Sci 2016;8:201-5.

17. Buttacavoli M, Albanese NN, Di Cara G, Alduina R, Faleri C, Gallo M, et al. Anticancer activity of biogenerated silver nanoparticles: An integrated proteomic investigation. Oncotarget 2018;9:9685-705. 